\title{
A failure to transfer control of keypecking from food reinforcement to escape from and avoidance of shock*
}

\section{BARRY SCHWARTZ and GEOFFREY COULTER Swarthmore College, Swarthmore, Pa. 19081}

Three pigeons, trained to keypeck for food reinforcement, were shifted to a procedure in which keypecks avoided or escaped electric shocks. Keypecking essentially ceased by the sixth session on this procedure. After 24 sessions of food reinforcement for pecking on a variable interval (VI) schedule, the avoidance-escape procedure was reintroduced, and keypecking ceased by the fourth session. Another period of VI food reinforcement, followed by another period of avoidance-escape, produced the same result. The same value of shock employed in the avoidance-escape procedure successfully eliminated the keypecking that produced it (punishment). These results support Bolles's (1970) discussion of species-specific defense reactions and are consistent with other failures to transfer control of responding from one reinforcer to another.

Keypecking in pigeons has proved extremely difficult to shape or maintain by escape or avoidance of electric shock (Azrin, 1959; Hoffman \& Fleshler, 1959; Rachlin, 1969; Rachlin \& Hineline, 1967; Hineline \& Rachlin, 1969). Though it is possible that the nature of the task simply strains the limited learning capacity of the pigeon, it seems more likely that the problem is in the nature of the required operant, since other responses have been more easily trained, e.g., head lifting (Hoffman \& Fleshler, 1959), locomotion (Macphail, 1968), wing flapping (Rachlin, 1969), treadle hopping (Smith \& Keller, 1970), and flying (Bedford \& Anger, 1968). In one of the more successful attempts to train keypeck escape responses, Rachlin (1969) employed a variant of Brown \& Jenkins's (1968) autoshaping procedure, which rapidly and reliably shapes keypecks for food reinforcement. Though keypeck escape responses did develop, wing-flap escape responses often developed instead and keypecking, when it did develop, gradually decreased in frequency over sessions.

A number of investigators have suggested that the nature of the required response is perhaps the most significant determinant of whether or not avoidance responding will be acquired rapidly or at all (Bolles, 1970; Seligman, 1970). According to Bolles, unless the required response is part of the organism's

*This research was supported in part by a grant from the Sloan Foundation to Swarthmore College. The authors are indebted to Kenneth Klothen for his valuable assistance in the conduct of the experiment and to Mryna Schwartz for her critical reading of the manuscript. Reprint requests should be sent to Barry Schwartz, Department of Psychology, Swarthmore College, Swarthmore, Pennsylvania 19081. Allen M. Schneider sponsors this paper and takes full editorial responsibility for its contents. species-specific defense repertoire (SSDR), avoidance learning will, at best, be protracted. On the basis of the difficulty Es have had in training keypeck avoidance, one would infer that pecking is not a species-specific defense reaction. The present experiment was designed to see whether this handicap might be overcome by attempting to train keypeck avoidance and escape responses after prolonged exposure to positive reinforcement schedules which maintained keypecking at high rates. After initial keypeck training for food, three exposures to an automatic avoidance-escape training procedure were interlaced with two prolonged exposures to a variable interval (VI) schedule of food reinforcement in an effort to transfer control of already acquired keypecking from food reinforcement to negative reinforcement.

\section{METHOD \\ Subjects}

Three experimentally naive pigeons, maintained at $80 \%$ of free-feeding weight, served as Ss.

\section{Apparatus}

One wall of a standard pigeon chamber housed a single response key, which could be illuminated with green light. A food magazine was located below the key, and an amber houselight was located above the key. The wall was painted flat black. The shock source was a Grason-Stadler shock generator (Model No. E1064), which was connected with alligator clips through the ceiling of the chamber to wire bands secured around each of the pigeon's wings (Hoffman \& Fleshler, 1959). The clips were attached to the wing bands at the start of each session, including those in which no shocks were scheduled.

\section{Procedure}

The pigeons were first trained to approach and eat from the feeder. They were then trained by successive approximations to peck the key. Keypecks were reinforced with $4 \mathrm{sec}$ access to grain. After three 50-reinforcement sessions of continuous reinforcements (CRF), the avoidance procedure was instituted. In each trial, the key was illuminated with green light. A peck in the first $7.5 \mathrm{sec}$ turned off the keylight and prevented shock. After the $7.5 \mathrm{sec}$ elapsed, a $1.3-\mathrm{mA}$ shock was delivered through the wing bands. The shock lasted for 6 sec, but a keypeck during this period turned off both the shock and the keylight. Each daily session consisted of 50 such avoidance-escape trials, separated by a variable intertrial interval, with a mean of $50 \mathrm{sec}$. After 21 sessions of this procedure, a variable interval 50 -sec (VI 50) schedule of food reinforcement was instituted for 24 sessions. Following this, the avoidance-escape procedure was reintroduced for 7 sessions, after which another 12 sessions of the VI 50 procedure were conducted. At this point, as a check on the effectiveness of the shock level being employed, a punishment procedure was introduced. Each peck in the VI 50 -sec schedule produced a $1.3-\mathrm{mA} 1-\mathrm{sec}$ shock through the wing bands. After six sessions, the punishment contingency was removed and the pigeons were run on the VI 50-sec schedule for 30 additional sessions. Finally, the avoidance-escape procedure 
Table 1

Summary of Procedures

\begin{tabular}{lc} 
Procedure & $\begin{array}{c}\text { Number } \\
\text { of Sessions }\end{array}$ \\
\hline CRF & 3 \\
AV-ESC & 21 \\
VI 50 & 24 \\
AV-ESC & 7 \\
VI 50 & 12 \\
VI 50 + PUN & 6 \\
VI 50 & 30 \\
AV-ESC & 9 \\
\hline
\end{tabular}

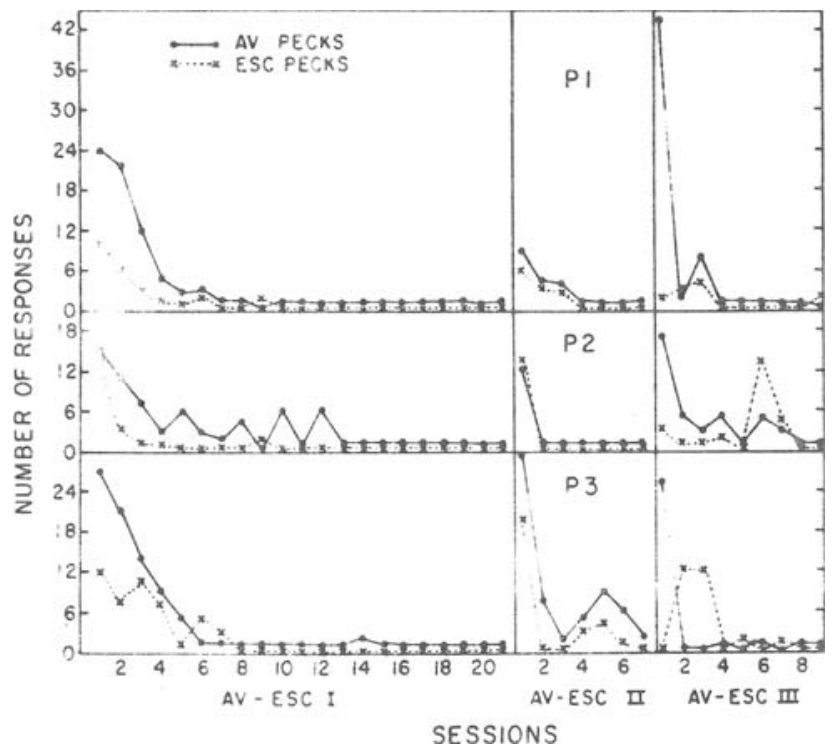

Fig. 1. Number of avoidance and escape responses emitted by each pigeon in each session of each exposure to the avoidance-escape procedure. The vertical lines separate the three interludes of avoidance-escape training. Extensive exposure to a VI schedule of food reinforcement was interpolated between the first and second and the second and third avoidance-escape procedures.

was reinstituted for nine sessions. The sequence of procedures is summarized in Table 1.

\section{RESULTS}

It is clear from Fig. 1, which presents the number of avoidance and escape responses for each pigeon in each session of the avoidance-escape procedures, that none of the pigeons learned to escape or avoid. The pigeons' first exposure to this procedure followed three sessions of CRF training. Hence, in the early sessions of avoidance training, there were substantial numbers of avoidance and escape responses. These early responses guaranteed that each pigeon experienced the consequences of pecking the illuminated key. Nevertheless, responding decreased steadily and ceased almost completely by the seventh session.

The second exposure to the avoidance procedure followed 24 sessions of a VI 50 -sec schedule of food reinforcement. At the end of that procedure, the pigeons were emitting 20-70 responses per minute (Fig. 2). Nevertheless, within two or three sessions of the avoidance procedure, responding ceased. A similar, though more gradual, cessation of responding occurred in the final avoidance procedure, after 48 additional sessions on the VI 50 schedule.

Figure 2 demonstrates that the shock level employed in the avoidance procedure was an effective aversive stimulus. The first two panels plot responses per minute in the last six sessions of the first two exposures to the VI 50-sec schedule (see Table 1). The third panel shows responses per minute in each of the sessions in which every VI peck was punished. The responding of all three pigeons decreased dramatically on this procedure, and Pigeon 1 ceased responding completely. It should be noted in this context that the problem of shock adaptation during a session, which has been reported by Rachlin (1969) and Rachlin \& Hineline (1967), was apparently not a problem in the present experiment. Pigeons were observed for entire avoidance-escape sessions, and the vigor of their responses to the shock did not diminish either during a particular shock or over the course of the sessions.

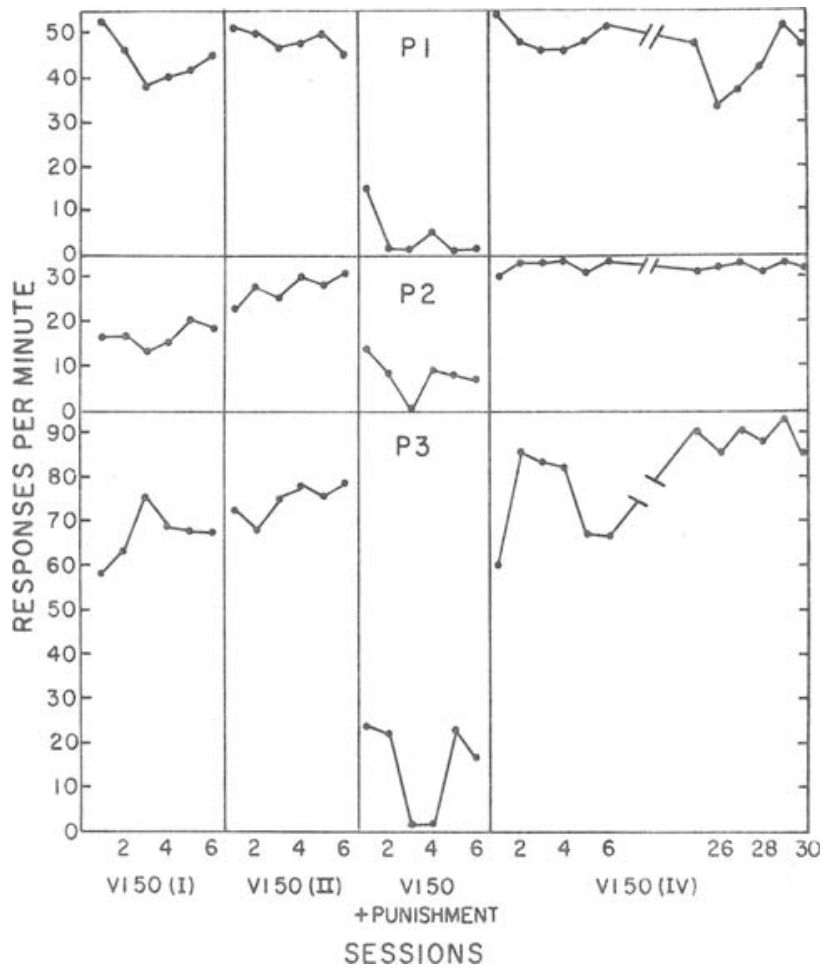

Fig. 2. Responses per minute for each pigeon in the VI 50 schedule of food reinforcement. The first two panels present the data from the last six sessions of the first two VI 50 interludes. The third panel presents the data from each of the sessions of VI 50 plus punishment. The last panel presents the data from the first and final six sessions of VI 50 which followed the punishment procedure. 


\section{DISCUSSION}

The results of the present experiment are unequivocal: Extended maintenance of keypecking on a schedule of food reinforcement did not facilitate the transfer of control of pecking to avoidance and escape contingencies. The fact that each avoidance-escape procedure began when the probability of keypecking was high guaranteed that some keypecks would occur and would be immediately followed by either the removal or the prevention of shock. Indeed, the pigeons routinely emitted 30 or more avoidance and escape responses on the first session of each avoidance procedure. Nevertheless, these reinforcements were not sufficient to maintain keypecking. Thus, the difficulty of keypeck avoidance procedures extends beyond the shaping of keypecks to the maintenance of keypecks which have already been shaped and are well established.

In presenting his argument that responses must be species-specific defense reactions (SSDRs) to be acquired as avoidance responses, Bolles explicitly rejected the interpretation that, since SSDRs encompass all that an animal will do in a danger situation, attempts to train non-SSDRs as avoidance responses will fail simply because the non-SSDRs will never occur. The SSDR model in this form is nothing but a discussion of variables which affect operant level. An implication of this view is that, if one were to insure the occurrence of the required response in the avoidance procedure, then whether or not it was an SSDR it would be maintained by successful escape or avoidance. The present procedure accomplished precisely that. Keypecks occurred frequently in the early avoidance sessions and may even have been at the top of the response hierarchy. Nevertheless, they were not maintained. Thus, the present experiment supports Bolles's contention that the failure of pigeons to learn keypeck avoidance involves more than a problem of operant level. What might also be involved is Seligman's (1970) notion that certain classes of responses can be associated with certain classes of consequences only with great difficulty, if at all.

On the other hand, a number of previous studies which attempted to transfer control of responding from one reinforcer to another, as in the present study, suggest that true transfer of control of responding is impossible (Azrin \& Huchinson, 1967; Hogan, 1964; Peterson, Ackil, Frommer, \& Hearst, 1972; Reynolds, Catania, \& Skinner, 1963; Wolin, 1968) because, when the reinforcer is changed, the topography of the behavior is changed significantly as well. Thus, the present experiment might be viewed as another instance of failure of transfer, because the nature of the reinforcers directly determines the nature of the response, an interpretation which is clearly compatible with Bolles's view (1970).

\section{REFERENCES}

Azrin, N. H. Some notes on punishment and avoidance. Journal of the Experimental Analysis of Behavior, 1959, 2, 260.

Azrin, N. H., \& Huchinson, R. R. Conditioning of the aggressive behavior of pigeons by a fixed-interval schedule of reinforcement. Journal of the Experimental Analysis of Behavior, 1967, 10, 395-402.

Bedford, J., \& Anger, D. Flight as an avoidance response in pigeons. Paper presented at the meeting of the Psychonomic Society, St. Louis, October 1968.

Bolles, R. C. Species-specific defense reactions and avoidance learning. Psychological Review, 1970, 77, 32-48.

Brown, P., \& Jenkins, H. B. Autoshaping of the pigeon's key peck. Journal of the Experimental Analysis of Behavior, 1968, 11, 1-8.

Hineline, P. N., \& Rachlin, H. Escape and avoidance of shock by pigeons pecking a key. Journal of the Experimental Analysis of Behavior, $1969,12,533-538$.

Hoffman, H. S., \& Fleshler, M. Aversive control with the pigeon. Journal of the Experimental Analysis of Behavior, 1959, 2, 213-218.

Hogan, J. A. Operant control of preening in pigeons. Journal of the Experimental Analysis of Behavior, 1964, 7, 351-354.

Macphail, E. M. Avoidance responding in pigeons. Journal of the Experimental Analysis of Behavior, 1968, 11, 625-632.

Peterson, G. B., Ackil, J. E., Frommer, G. P., \& Hearst, E. S. Conditioned approach and contact behavior toward signals for food or brain-stimulation reinforcement. Science, 1972, 177 1009-1011.

Rachlin, H. Autoshaping of key pecking in pigeons with negative reinforcement. Journal of the Experimental Analysis of Behavior, 1969, 12, 521-531.

Rachlin, H., \& Hineline, P. N. Training and maintenance of key pecking in the pigeon by negative reinforcement. Science, 1967, 157, 954-955.

Reynolds, G. S., Catania, A. C., \& Skinner, B. F. Conditioned and unconditioned aggression in pigeons. Journal of the Experimental Analysis of Behavior, 1963, 6, 73-74.

Seligman, M. E. P. On the generality of the laws of learning. Psychological Review, 1970, 77, 406-418.

Smith, R. F., \& Keller, R. F. Free-operant avoidance in the pigeon using a treadle response. Journal of the Experimental Analysis of Behavior, 1970, 13, 211-214.

Wolin, B. R. Difference in manner of pecking a key between pigeons reinforced with food and with water. Paper read at the Conference on the Experimental Analysis of Behavior, 1948. Reprinted in A. C. Catania (Ed.), Contemporary research in operant behavior. Glenview, Ill: Scott, Foresman, 1968.

(Received for publication January $31,1973$. ) 